\title{
Ammonium cycling under a strong oxygen gradient associated with the Oxygen Minimum Zone off northern Chile $\left(\sim 23^{\circ} \mathrm{S}\right)$
}

\author{
Verónica Molina ${ }^{1,2,3, *}$, Laura Farías ${ }^{2,3,4}$, Yoanna Eissler ${ }^{3}$, Luis Antonio Cuevas ${ }^{1,3}$, \\ Carmen E. Morales ${ }^{3,4}$, Rubén Escribano ${ }^{3,4}$
}

\begin{abstract}
${ }^{1}$ Programa de Postgrado, Departamento Oceanografía, ${ }^{2}$ Programa Regional de Oceanografía Física y Clima (PROFC), ${ }^{3}$ Centro de Investigación Oceanográfica en el Pacífico Sur-Oriental (FONDAP-COPAS), ${ }^{4}$ Departamento de Oceanografía, Universidad de Concepción, PO Box 160-C, Correo 3, Concepción, Chile
\end{abstract}

\begin{abstract}
Ammonium $\left(\mathrm{NH}_{4}^{+}\right)$cycling rates under different dissolved oxygen (DO) conditions in the water column, at a coastal upwelling area off northern Chile $\left(\sim 23^{\circ} \mathrm{S}\right)$, were estimated. $\mathrm{Net}^{\mathrm{NH}}{ }_{4}^{+}$ regeneration (eukaryotes and prokaryotes) and $\mathrm{NH}_{4}{ }^{+}$oxidation (nitrifying bacteria) rates were examined by means of selective inhibitor assays (cycloheximide and allylthiourea) under dark conditions. Whole water samples for incubations were taken in the oxycline, low-DO zone (30 m; $69 \mu \mathrm{M}$ DO), and in the upper boundary of the Oxygen Minimum Zone (OMZ), suboxic zone (50 $\mathrm{m}_{i}<5 \mu \mathrm{M}$ DO). Net $\mathrm{NH}_{4}{ }^{+}$regeneration and consumption were also determined in size-fractionated $(<200 \mu \mathrm{m})$ experiments with water samples obtained from the suboxic zone $(50 \mathrm{~m})$ and the base of the mixed layer, oxic zone (15 m; $104 \mu \mathrm{M} \mathrm{DO})$. Results indicate that, in the oxycline, prokaryotes were responsible for most of the $\mathrm{NH}_{4}{ }^{+}$cycling, with regeneration and oxidation rates of $\sim 1.3$ and $0.56 \mu \mathrm{M} \mathrm{d}^{-1}$, respectively. This, in turn, favoured $\mathrm{NH}_{4}{ }^{+}$and $\mathrm{NO}_{3}^{-}$accumulation in this layer, characterised by strong physicalchemical gradients (temperature, salinity and DO), and accompanied by lower abundances of cyanobacteria $\left(0.09 \times 10^{5}\right.$ cells ml $\left.{ }^{-1}\right)$ and heterotrophic nanoflagellates $\left(\mathrm{HNF} ; 15.6 \mathrm{cells} \mathrm{ml}^{-1}\right)$. In the oxic and suboxic layers, eukaryotes appear to be the main contributors to net $\mathrm{NH}_{4}{ }^{+}$regeneration (4.6 to $17.7 \mu \mathrm{M} \mathrm{d}^{-1}$ ), supporting a high net $\mathrm{NH}_{4}{ }^{+}$dark prokaryote consumption, including high potential $\mathrm{NH}_{4}{ }^{+}$oxidation (0.95 to $1.34 \mu \mathrm{M} \mathrm{d}^{-1}$ ) in the suboxic zone. The abundances of bacteria, cyanobacteria and HNF were higher in these layers $\left(>1.2 \times 10^{6},>0.9 \times 10^{5}\right.$ and $>37$ cells ml $^{-1}$, respectively), indicating a potential large impact on $\mathrm{NH}_{4}{ }^{+}$cycling.
\end{abstract}

KEY WORDS: Ammonium regeneration · Nitrification potential $\cdot$ Bacterioplankton $\cdot$ Heterotrophic nanoflagellates · Oxygen Minimum Zone · Upwelling area · Northern Chile

- Resale or republication not permitted without written consent of the publisher

\section{INTRODUCTION}

The coastal area off northern Chile $\left(\sim 18\right.$ to $\left.24^{\circ} \mathrm{S}\right)$ has been characterised by intermittent wind-driven upwelling events (Blanco et al. 2001), and with a high spatial and temporal variability in total primary production (0.1 to $9 \mathrm{~g} \mathrm{C} \mathrm{m}^{-2} \mathrm{~d}^{-1}$; Daneri et al. 2000). Besides the classical food web sustained by microphytoplankton $(>50 \%)$, this upwelling area contributes to a microbial food web, particularly important during El Niño periods (Iriarte \& González 2004,
Vargas \& González 2004). This area also exhibits a permanent Oxygen Minimum Zone (OMZ) (defined by levels $<0.2 \mathrm{ml}$ dissolved oxygen [DO] $\mathrm{l}^{-1}$; Kamykowski \& Zentara 1990), associated with the Equatorial Subsurface Waters (ESSW) and transported from the north by the Peru-Chile Undercurrent (Brandhorst 1971).

The upper boundary of the OMZ off northern Chile is represented by sharp DO, temperature and salinity gradients, including a shallow salinity minimum (SSM; $\sim 25 \mathrm{~m}$ depth), with all variables contributing to high water column stratification when upwelling is not 
active (Blanco et al. 2001). The oxycline is normally quite shallow (Morales et al. 1999) and usually situated within the euphotic zone ( $80 \mathrm{~m}$ depth; $0.1 \%$ light), generating a unique physical-chemical environment; the co-existence of low-light and suboxic waters. This condition creates a favourable environment for higher abundances of bacterioplankton in the upper boundary of the OMZ, including the cyanobacteria Synechococcus spp. and Prochlorococcus spp., which forms a secondary fluorescence maximum (O. Ulloa unpubl. data), as occurs in other OMZs (e.g. Arabian Sea and Eastern Tropical North Pacific; Goericke et al. 2000).

The presence of a cyanobacteria-dominated community layer may represent an additional carbon source for bacterivores (such as heterotrophic nanflagellates [HNF]) that are able to live under low DO concentrations, enhancing a microbial food web (Park \& Cho 2002). In turn, HNF and other eukaryotes are expected to contribute a high percentage of $\mathrm{NH}_{4}{ }^{+}$regeneration (e.g. >73\%; Maguer et al. 1999) via excretion, a process coupled with higher $\mathrm{NH}_{4}{ }^{+}$oxidation rates (the first step of nitrification), as observed in the upper boundary of the OMZ off Peru (Ward et al. 1989, Lipschultz et al. 1990). The $\mathrm{NH}_{4}{ }^{+}$oxidation process is crucial for nitrogen $(\mathrm{N})$ cycling in OMZs due to the coupling of $\mathrm{NH}_{4}{ }^{+}$regeneration with denitrification, the main process contributing to $\mathrm{N}$ loss in the ocean by means of gas production $\left(\mathrm{N}_{2} \mathrm{O}\right.$ and $\mathrm{N}_{2}$ i Codispoti et al. 2001).

So far, $\mathrm{N}$ cycling studies in OMZ regions have been focused on the assessments of $\mathrm{NO}_{3}^{-}$reduction and $\mathrm{NH}_{4}{ }^{+}$oxidation processes, while far less attention has been given to the evaluation of $\mathrm{NH}_{4}{ }^{+}$regeneration (i.e. excretion and remineralisation) and to the identification of the main contributors to this process. This study evaluates the relative contribution of eukaryotes and prokaryotes to the net $\mathrm{NH}_{4}{ }^{+}$regeneration and consumption, and assesses the $\mathrm{NH}_{4}{ }^{+}$consumption by nitrification in the water column, in a coastal upwelling area off northern Chile $\left(\sim 23^{\circ} \mathrm{S}\right)$ during the austral spring. For this purpose, natural planktonic assemblages obtained from seawater samples with different DO conditions were incubated with a combination of selective inhibitors halting the different $\mathrm{NH}_{4}{ }^{+}$cycling processes.

\section{MATERIALS AND METHODS}

The study site (Fig. 1), located off Mejillones Bay (Stn ABGQ; $22^{\circ} 51^{\prime} 13^{\prime \prime} \mathrm{S}, 70^{\circ} 33^{\prime} 05^{\prime \prime} \mathrm{W}$ ), was visited in December 2002 on board the RV 'Purihaalar' (University of Antofagasta). The sampling first considered the measurement of the physical and chemical parameters (temperature, salinity, fluorescence and oxygen) with a
CTD-FO. These casts were examined in terms of the DO to select the depths for collecting water for the experiments, including oxic $(104 \mu \mathrm{M})$, low-DO $(69 \mu \mathrm{M})$ and suboxic $(5 \mu \mathrm{M})$ zones. In addition, discrete water samples for $\mathrm{DO}, \mathrm{NH}_{4}{ }^{+}, \mathrm{NO}_{3}{ }^{+}$and $\mathrm{NO}_{2}{ }^{-}$concentrations, and for $\mathrm{HNF}$, bacteria and cyanobacteria abundances, were collected in Niskin bottles (5 l).

Experimental design to evaluate $\mathrm{NH}_{4}{ }^{+}$regeneration and consumption contributors. Non-fractionated experiments for $\mathrm{NH}_{4}{ }^{+}$regeneration and consumption via nitrification were carried out using water samples from the oxycline $(30 \mathrm{~m})$ and suboxic $(50 \mathrm{~m})$ layers. Seawater (12 l) was collected from each depth (03:00 h) and stored in the dark with running surface seawater until arriving at the laboratory in Antofagasta $(\sim 5 \mathrm{~h})$. In the laboratory, the seawater was carefully distributed (in order to avoid further oxygenation) into 4 glass amber bottles $(2.5 \mathrm{l})$. One of the bottles was amended with a well-recognised $\mathrm{NH}_{4}{ }^{+}$ oxidation inhibitor of autotrophic $\mathrm{NH}_{4}{ }^{+}$-oxidizing bacteria, allylthiourea (ATU), at a concentration of $0.09 \mu \mathrm{M}$ (Bianchi et al. 1997). A second bottle was treated with an inhibitor of eukaryotic protein synthesis, cycloheximide (CX), at a concentration of $100 \mathrm{mg}$ $\mathrm{I}^{-1}$ (Campbell \& Carpenter 1986, Wheeler \& Kirchman 1986, Fischer \& Pusch 1999). A third bottle was amended with a combination of both inhibitors (ATU $+\mathrm{CX}$ ) and a fourth bottle was used as a control (no treatment). Initial concentrations of dissolved inor-

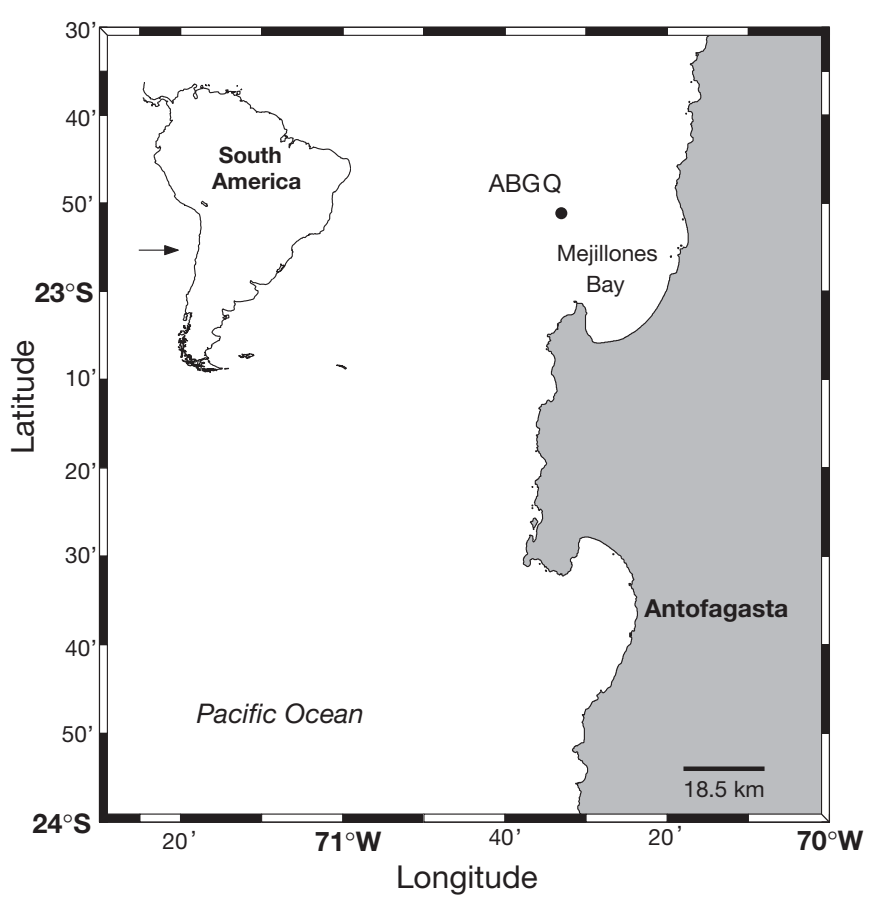

Fig. 1. Study site off northern Chile (ABGQ: sampling station) 
ganic $\mathrm{N}\left(\mathrm{DIN}=\mathrm{NH}_{4}{ }^{+}, \mathrm{NO}_{3}{ }^{-}, \mathrm{NO}_{2}^{-}\right)$were measured in each bottle. After nutrient sub-sampling, the remaining water in each treatment bottle was distributed into 3 smaller glass bottles $(500 \mathrm{ml})$, which were completely filled; these bottles were incubated for $7 \mathrm{~h}$ in the dark and under controlled temperature $\left(13^{\circ} \mathrm{C}\right)$. At the end of the incubation time, each bottle was subsampled for DIN determination. Potential $\mathrm{NH}_{4}{ }^{+}$oxidation rates were also evaluated under substrate addition since $\mathrm{CX}$, due to its composition, increases the natural $\mathrm{NH}_{4}{ }^{+}$concentrations $(\sim 0.1 \mu \mathrm{M}$; Wheeler \& Kirchman 1986).

Size-fractionated $(<200 \mu \mathrm{m}$ mesh) experiments on $\mathrm{NH}_{4}{ }^{+}$cycling, also including $\mathrm{HNF}$, bacteria and cyanobacteria changes in abundance during the incubations, were performed in the oxic $(15 \mathrm{~m})$ and suboxic $(50 \mathrm{~m})$ levels. Seawater was collected (09:15 h) and distributed into 4 bottles $(500 \mathrm{ml})$; 2 were amended with $\mathrm{CX}$ and the other 2 were not treated (control). For the determination of initial $\mathrm{NH}_{4}^{+}$concentration, subsamples were taken from 1 bottle, while samples for determination of HNF, bacteria and cyanobacteria abundances were taken from the other bottle. After this, the bottles were incubated on-deck $(\sim 4 \mathrm{~h})$, in the dark, and cooled down with running surface seawater $\left(\sim 17^{\circ} \mathrm{C}\right)$. Sub-sampling for final conditions was then undertaken for the same variables.

Analytical methods and data analyses. DO (125 ml, triplicate) was analysed following a modified Winkler method (Williams \& Jenkinson 1982). $\mathrm{NH}_{4}{ }^{+}$(40 ml, triplicate) was determined using the fluorometric method (Holmes et al. 1999) with a Turner Designs 10-AU fluorometer. $\mathrm{NO}_{2}^{-}$(10 ml, duplicate) was immediately analysed on board, using a standard colorimetric technique (Parsons et al. 1984). Samples for $\mathrm{NO}_{3}{ }^{-}$and $\mathrm{NO}_{2}{ }^{-}$ determination were recovered, filtered $(\mathrm{GF} / \mathrm{F}$, Whatman) and stored frozen until later analysis by an automated analyser (ALPKEM, Flow Solution IV). Samples for bacterioplankton and HNF were immediately fixed with glutaraldehyde $(2 \%)$ and stored in the dark at $4^{\circ} \mathrm{C}$ until analysis. Bacterioplankton $(2 \mathrm{ml})$ and HNF $(20 \mathrm{ml})$ samples were filtered onto 0.2 and $0.8 \mu \mathrm{m}$ black Millipore filters, respectively, and stained with DAPI (10 $\mu \mathrm{g}$ $\mathrm{ml}^{-1}$; Porter \& Feig 1980). Thereafter, these filters (duplicate) were mounted on glass slides and stored frozen $\left(-20^{\circ} \mathrm{C}\right)$ until examined. Particle identification and counting were performed under up to $1600 \times$ magnification using a Zeiss epifluorescence microscope (Axioskop 2-Plus equipped with a blue and UV light filter set). Cyanobacteria were distinguished from heterotrophic bacteria by the presence of autofluorescent pigments (phycoerythrin or phycocyanin) in the former. For each sample, 10 and 50 fields were randomly selected to count bacterioplankton and HNF, respectively.
Net rates of DIN change through time (NR) in each treatment were calculated by subtracting the average values of the final DIN concentration from the average values of the initial DIN concentration, and then dividing by the incubation time: $\mathrm{NR}_{\text {DIN TREATMENT }}=[$ (final DIN concentration - initial DIN concentration)/time].

The rate of DIN change was averaged from 3 replicates and its uncertainty $( \pm)$ was calculated using the propagation error and expressed in terms of $\mu \mathrm{M} \mathrm{d}^{-1}$. The standard deviations derived from the average rates, and the initial and final DIN concentrations were used to estimate the propagation error. A positive value indicates nutrient appearance or production, while a negative value represents disappearance or consumption through time. In size-fractionated experiments, only 1 rate and propagation error for each treatment (control and CX) was obtained. Significant differences between treatments $(\mathrm{p}<0.05)$, considering 3 replicates per $\mathrm{NR}_{\mathrm{DIN}}$, were examined by a Student's $t$-test.

Estimation of the main contributors to $\mathrm{NH}_{4}{ }^{+}$cycling. $\mathrm{NH}_{4}{ }^{+}$cycling rates were calculated from the differences between the average rates of the corresponding treatments where 1 or $2 \mathrm{NH}_{4}{ }^{+}$cycling contributors were inhibited (Table 1), distinguishing between eukaryotes, prokaryotes and/or $\mathrm{NH}_{4}{ }^{+}$-oxidizing bacteria (AOB). $\mathrm{NH}_{4}{ }^{+}$regeneration and consumption are 'net' rates because the experimental approach includes both production and uptake processes (Table 1), with the predominance of one process over the other depending on the treatment.

Prokaryote influence on $\mathrm{NH}_{4}{ }^{+}$regeneration $\left(\mathrm{NR}_{\mathrm{NH} 4+}\right.$ PROK REGEN) is expected when a positive $(+) \mathrm{NH}_{4}{ }^{+}$rate appears in the CX treatments (CX or ATU $+\mathrm{CX})$ :

$$
\mathrm{NR}_{\mathrm{NH} 4+\text { PROK REGEN }}=+\mathrm{NR}_{\mathrm{CX}} \text { or }+\mathrm{NR}_{\mathrm{ATU}+\mathrm{CX}}
$$

Prokaryote contribution to $\mathrm{NH}_{4}{ }^{+}$consumption $\left(\mathrm{NR}_{\mathrm{NH} 4+}\right.$ PROK CONSUMPTION $)$ is expected when a negative (-) $\mathrm{NH}_{4}{ }^{+}$rate appears in the CX treatments:

$$
\mathrm{NR}_{\mathrm{NH} 4+\text { PROK CONSUMPTION }}=-\mathrm{NR}_{\mathrm{CX}} \text { or }-\mathrm{NR}_{\mathrm{ATU}+\mathrm{CX}}
$$

Eukaryote influence on $\mathrm{NH}_{4}{ }^{+}$regeneration $\left(\mathrm{NR}_{\mathrm{NH} 4+}\right.$ EUK REGEN) is expected when a positive or zero $\mathrm{NH}_{4}{ }^{+}$rate appears in the control and a negative $\mathrm{NH}_{4}{ }^{+}$rate in the CX treatment; in this case, the rate is calculated from:

$$
\mathrm{NR}_{\mathrm{NH} 4+\text { EUK REGEN }}=\mathrm{NR}_{\text {Control }}-\mathrm{NR}_{\mathrm{CX}}
$$

Eukaryote influence on $\mathrm{NH}_{4}{ }^{+}$consumption $\left(\mathrm{NR}_{\mathrm{NH} 4+}\right.$ EUK CONSUMPTION) is expected if a negative $\mathrm{NH}_{4}^{+}$rate appears in the control and a positive or less negative $\mathrm{NH}_{4}{ }^{+}$rate in the CX treatment; the rate is calculated from:

$$
\mathrm{NR}_{\mathrm{NH} 4+\text { EUK CONSUMPTION }}=\mathrm{NR}_{\mathrm{CX}}-\mathrm{NR}_{\text {Control }}
$$

AOB activity under natural conditions $\left(R_{\mathrm{NH} 4+}\right.$ OxID naturali no $\mathrm{NH}_{4}{ }^{+}$addition) was calculated from the difference 
Table 1. $\mathrm{NH}_{4}{ }^{+}$cycling contributors expected to be active (+) and inhibited (-) in each treatment. CX: cycloheximide; ATU: allylthiourea; ATU + CX: combination of both inhibitors; + : process-active $;$-: process-inhibited

\begin{tabular}{|c|c|c|c|c|c|c|}
\hline \multirow[t]{2}{*}{ Treatment } & \multicolumn{2}{|c|}{$\mathrm{NH}_{4}^{+}$regeneration } & \multicolumn{3}{|c|}{$\mathrm{NH}_{4}{ }^{+}$consumption } & \multirow{2}{*}{$\begin{array}{l}\text { Summary of contributors } \\
\text { to each net } \\
\mathrm{NH}_{4}^{+} \text {rates of change } \\
\left(\mathrm{NR}_{\mathrm{NH} 4+}\right)\end{array}$} \\
\hline & $\begin{array}{l}\text { Eukaryotes } \\
\text { (excretion) }\end{array}$ & $\begin{array}{l}\text { Prokaryotes } \\
\text { (remineral- } \\
\text { isation) }\end{array}$ & $\begin{array}{l}\mathrm{NH}_{4}^{+} \text {oxidation } \\
\text { (autotrophic } \mathrm{NH}_{4}^{+} \\
\text {oxidizing } \\
\text { bacteria, AOB) }\end{array}$ & $\begin{array}{c}\text { Eukaryotes } \\
\mathrm{NH}_{4}^{+} \text {uptake } \\
\text { (photoauto- } \\
\text { troph) }\end{array}$ & $\begin{array}{c}\text { Prokaryotes } \\
\mathrm{NH}_{4}^{+} \text {uptake } \\
\text { (photoauto- } \\
\text { trophic and } \\
\text { heterotrophic } \\
\text { bacteria) }\end{array}$ & \\
\hline Control & + & + & + & + & + & $\begin{array}{l}\mathrm{NR}_{\mathrm{NH} 4+\text { Control }}= \\
\text { Total plankton community }\end{array}$ \\
\hline CX & - & + & + & - & + & $\begin{array}{l}\mathrm{NR}_{\mathrm{NH} 4+\mathrm{CX}}=\text { Prokaryote } \\
\text { community uptake (-) or } \\
\text { regeneration (+) }\end{array}$ \\
\hline ATU & + & + & - & + & + & $\begin{array}{l}\mathrm{NR}_{\mathrm{NH} 4+\mathrm{ATU}}=\text { Total plankton } \\
\text { community }-\mathrm{AOB}\end{array}$ \\
\hline $\mathrm{ATU}+\mathrm{CX}$ & - & + & - & - & + & $\begin{array}{l}\mathrm{NR}_{\mathrm{NH} 4+} \mathrm{ATU}+\mathrm{CX}=\text { Prokaryote } \\
\text { community - AOB uptake (-) } \\
\text { or regeneration }(+)\end{array}$ \\
\hline
\end{tabular}

between the $\mathrm{NH}_{4}{ }^{+}$net rate of change in the ATU treatment versus the control (when $\mathrm{NH}_{4}{ }^{+}$oxidation is inhibited, a higher $\mathrm{NH}_{4}{ }^{+}$production is expected in the ATU treatment). Following Lam et al. (2004):

$$
R_{\mathrm{NH} 4+\text { OXID natural }}=\mathrm{NR}_{\mathrm{ATU}}-\mathrm{NR}_{\text {Control }}
$$

AOB activity under potential conditions $\left(R_{\mathrm{NH} 4+}\right.$ OxID potentiali with $\mathrm{NH}_{4}{ }^{+}$enrichment introduced by CX) was calculated following the same approach mentioned above but using CX treatments; in this case:

$$
R_{\mathrm{NH} 4+\text { OXID potential }}=\mathrm{NR}_{\mathrm{ATU}+\mathrm{CX}}-\mathrm{NR}_{\mathrm{CX}}
$$

In addition, AOB activity was calculated from the difference between the $\mathrm{NO}_{2}^{-}$rates of change in the ATU treatments (ATU and ATU + CX), and the control and CX treatment (when $\mathrm{NH}_{4}{ }^{+}$oxidation is not inhibited, a higher $\mathrm{NO}_{2}^{-}$production is expected). In this way, natural and potential $\mathrm{NH}_{4}{ }^{+}$oxidation rates were also calculated as follows: and

$$
R_{\mathrm{NH} 4+\text { OXID natural }}=\mathrm{NR}_{\mathrm{NO} 2-\text { Control }}-\mathrm{NR}_{\mathrm{NO} 2-\mathrm{ATU}}
$$

$$
R_{\mathrm{NH} 4+\text { OXID potential }}=\mathrm{NR}_{\mathrm{NO} 2-\mathrm{CX}}-\mathrm{NR}_{\mathrm{NO} 2-\mathrm{ATU}+\mathrm{CX}}
$$

ATU inhibits $\mathrm{NH}_{4}{ }^{+}$oxidation, but not $\mathrm{NO}_{2}^{-}$oxidation; however, if a high coupling between both processes exists, and if ATU stops $\mathrm{NO}_{2}^{-}$production by AOB, then $\mathrm{NO}_{2}^{-}$disappearance associated with $\mathrm{NO}_{2}^{-}$ oxidation occurs if no other process, such as $\mathrm{NO}_{2}^{-}$ reduction, is acting. The $\mathrm{NO}_{2}^{-}$oxidation rate is, therefore, estimated from the direct $\mathrm{NO}_{2}{ }^{-}$disappearance rate in the ATU treatment, and the indirect $\mathrm{NO}_{3}{ }^{-}$ appearance rate in the control and $\mathrm{CX}$ treatment (Bianchi et al. 1997).

\section{RESULTS}

\section{Water column physical, chemical and biological conditions}

The vertical distribution of the physical-chemical and biological variables at the study site, obtained from the 09:00 h sampling, are shown in Fig. 2. Below $15 \mathrm{~m}$, temperature $(T)$ decreased rapidly with depth (Fig. 2a), from $16.5^{\circ} \mathrm{C}$ at the surface to $13^{\circ} \mathrm{C}$ at $25 \mathrm{~m}$ depth, the base of the thermocline. Salinity (S) distribution also decreased from $\sim 34.8$ at the surface to 34.5 at $25 \mathrm{~m}$ depth (the Shallow Salinity Minimum, SSM), and then increased sharply to $>34.8$ towards $50 \mathrm{~m}$ (Fig. 2a). The strong $T$ and $\mathrm{S}$ gradients and the derived density distribution (Fig. 2a) are indicative of water column stratification and, thus, reduced vertical mixing. Except for the $40 \mathrm{~m}$ depth data, DO concentrations from the CTD sensor and the Winkler method presented a good Spearman correlation value $(r=0.8$; $\mathrm{p}=0.004$ ). DO distribution (Fig. 2b) showed higher concentrations at the surface $(>100 \mu \mathrm{M})$, a sharp oxycline from the base of the mixed layer $(\sim 15 \mathrm{~m})$ and down to $35 \mathrm{~m}$ depth. Below this depth, according to the CTD-DO data, suboxic levels $(\leq 5 \mu \mathrm{M})$ signal the influence of ESSW and the upper portion of the OMZ. The relative fluorescence (Fig. 2b) showed 2 maxima, the primary fluorescence peak between the surface and $25 \mathrm{~m}$ depth and a weakly defined secondary fluorescence peak between 30 and $60 \mathrm{~m}$ depth.

$\mathrm{NH}_{4}{ }^{+}$concentration (Fig. 2c) presented a maximum at $15 \mathrm{~m}$ depth $(0.5 \mu \mathrm{M})$, and then gradually diminished until being undetectable below $50 \mathrm{~m}$ depth. $\mathrm{NO}_{2}^{-}$con- 


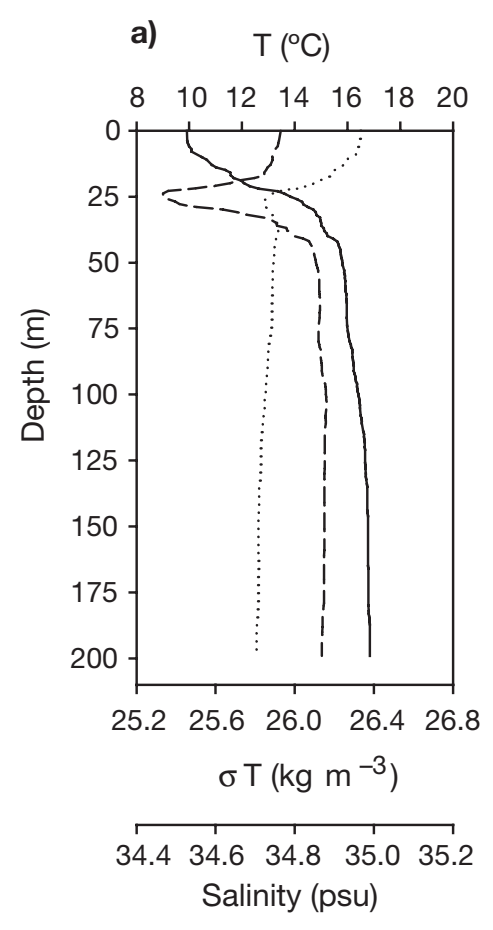

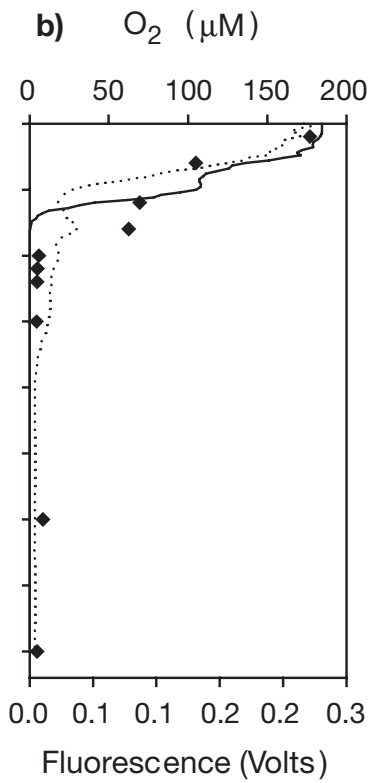

Fluorescence (Volts)

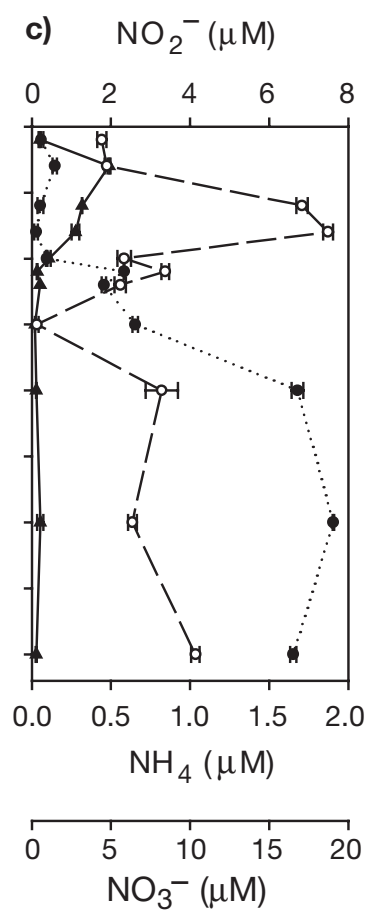

d) $\mathrm{HNF}\left(\right.$ cells $\left.\mathrm{ml}^{-1}\right)$

Fig. 2. Vertical distribution of physical and chemical variables, and the abundance of planktonic micro-organisms (mean \pm SD) in the water column at the sampling station. (a) Temperature (T): dotted line; Salinity (S): dashed line; $\sigma T$ : solid line; (b) Fluorescence: dotted line, DO-CTD: solid line (below the detection limit at $>40 \mathrm{~m}$ depth); DO-Winkler: $\bullet_{i}$ (c) $\mathrm{NO}_{2}^{-}: \bullet$ dotted line;

$\mathrm{NO}_{3}^{-}$: O dashed line; $\mathrm{NH}_{4}{ }^{+}: \boldsymbol{\Lambda}$ solid line; and (d) HNF: $\bullet$ dotted line; bacteria: $\diamond$ dashed line; cyanobacteria: $\mathbf{a}$ solid line

centration (Fig. 2c) displayed a small maximum $(0.5 \mu \mathrm{M})$ also centred at $15 \mathrm{~m}$ depth, which decreased to near 0 below this depth, and then increased gradually between 50 and $100 \mathrm{~m}$ depth, reaching its highest concentrations $(>7 \mu \mathrm{M})$ below this layer. $\mathrm{NO}_{3}{ }^{-}$concentration (Fig. 2c) also presented a bimodal distribution, with a maximum centred between 30 and $40 \mathrm{~m}$ depth $(\geq 17 \mu \mathrm{M})$, minimum values between 50 to $75 \mathrm{~m}$, coinciding with the increase in $\mathrm{NO}_{2}^{-}$concentration, and again higher values (8 to $10 \mu \mathrm{M}$ ) below this depth.

Bacteria, cyanobacteria and HNF abundances (Fig. 2d) were highest at the surface, and steadily decreased towards $30 \mathrm{~m}$ depth (from $4.23 \times 10^{6}$ to $0.54 \times 10^{6}, 0.24 \times 10^{5}$ to $0.09 \times 10^{5}$, and from 442.7 to 15.6 cells ml${ }^{-1}$, respectively). At $40 \mathrm{~m}$, the abundances of the bacteria and cyanobacteria increased slightly, resulting in a secondary maximum at $50 \mathrm{~m}$ depth

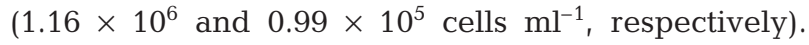
HNF presented a weakly defined maximum at 40 to $50 \mathrm{~m}$ depth, with abundances ranging from 36.5 to 44.7 cells ml${ }^{-1}$.

In summary, the depths selected for the incubation experiments, i.e. 15,30 and $50 \mathrm{~m}$, represented $3 \mathrm{DO}$ conditions: oxic $(104 \mu \mathrm{M})$ at the base of the mixed layer, low-DO $(69 \mu \mathrm{M})$ at the oxycline, and suboxic $(5 \mu \mathrm{M})$ at the upper boundary of the OMZ. The upper boundary of the OMZ appears well demarked at $50 \mathrm{~m}$ depth, below which the typical OMZ core conditions were observed, including suboxic levels, a Secondary Nitrite Maximum (SNM), a $\mathrm{NO}_{3}{ }^{-}$deficit, undetectable $\mathrm{NH}_{4}{ }^{+}$concentrations, and secondary bacteria and cyanobacteria maxima. In contrast, the base of the mixed layer and oxycline contained lower $\mathrm{NO}_{2}{ }^{-}$concentrations, $\mathrm{NO}_{3}{ }^{-}$maxima and higher $\mathrm{NH}_{4}{ }^{+}$concentrations.

\section{$\mathrm{NH}_{4}{ }^{+}$regeneration and consumption contributors under a DO gradient}

DIN mean rates of change in all the treatments, from which the different processes were estimated, are presented in Table 2. An influence of prokaryotes on $\mathrm{NH}_{4}{ }^{+}$ cycling, including different types of metabolism (see Table 1), was directly observed in the CX treatment in all the experiments (size-fractionated and non-fractionated) and in the ATU + CX treatment (without AOB influence) only in the non-fractionated incubations. In the oxycline zone, $\mathrm{NH}_{4}{ }^{+}$appearance rates in the $\mathrm{CX}$ treatment, comparable to those in the control ( $t$-test, $p=0.45$ ), indicated that prokaryotes were responsible for net $\mathrm{NH}_{4}{ }^{+}$regeneration in the order of $\sim 1.33 \mu \mathrm{M} \mathrm{d}^{-1}$ $(\mathrm{CX}+\mathrm{ATU}$; Table 2$)$. In the oxic and suboxic layers, $\mathrm{NH}_{4}{ }^{+}$disappearance rates in the $\mathrm{CX}$ treatment, and 
Table 2. Net DIN mean nutrient rates (NR) of appearance $(+)$ or disappearance $(-)$ during experimental incubations of nonfractionated and size-fractionated $(<200 \mu \mathrm{m})$ water column samples taken from the oxic, oxycline and suboxic zones. CX: cycloheximide; ATU: allylthiourea; ATU + CX: combination of both inhibitors; \pm : propagation error; nm: not measured

\begin{tabular}{|c|c|c|c|c|}
\hline Sample origin and experimental incubation & $\begin{array}{c}\text { Treatment } \\
\left(\mu \mathrm{M} \mathrm{d}^{-1}\right)\end{array}$ & $\begin{array}{l}\mathrm{NRNH}_{4}^{+} \\
\left(\mu \mathrm{M} \mathrm{d}^{-1}\right)\end{array}$ & $\begin{array}{l}\mathrm{NRNO}_{2}^{-} \\
\left(\mu \mathrm{M} \mathrm{d}^{-1}\right)\end{array}$ & $\begin{array}{l}\mathrm{NRNO}_{3}^{-} \\
\left(\mu \mathrm{M} \mathrm{d}^{-1}\right)\end{array}$ \\
\hline \multirow{4}{*}{$\begin{array}{l}\text { Oxycline (low-DO zone; } 69 \mu \mathrm{M}) \\
(30 \mathrm{~m} \text {, non-fractionated) }\end{array}$} & Control & $0.30 \pm 0.18$ & $0.73 \pm 0.25$ & $26.7 \pm 2.4$ \\
\hline & ATU & $0.71 \pm 1.28$ & $0.55 \pm 0.16$ & $19.9 \pm 4.9$ \\
\hline & $\mathrm{CX}$ & $0.29 \pm 0.83$ & $0.68 \pm 0.32$ & $5.3 \pm 2.5$ \\
\hline & $\mathrm{ATU}+\mathrm{CX}$ & $1.33 \pm 2.04$ & $0.12 \pm 0.21$ & $-4.6 \pm 1.4$ \\
\hline \multirow{4}{*}{$\begin{array}{l}\text { Upper border of the OMZ (suboxic zone; } 5 \mu \mathrm{M} \text { ) } \\
(50 \mathrm{~m} \text {, non-fractionated) }\end{array}$} & Control & $0.77 \pm 0.41$ & $-0.87 \pm 0.27$ & $-15.4 \pm 9.5$ \\
\hline & ATU & $0.58 \pm 0.14$ & $-0.26 \pm 0.30$ & $18.3 \pm 8.7$ \\
\hline & $\mathrm{CX}$ & $-3.86 \pm 0.54$ & $0.67 \pm 0.48$ & $13.7 \pm 8.1$ \\
\hline & $\mathrm{ATU}+\mathrm{CX}$ & $-2.91 \pm 0.60$ & $-0.67 \pm 0.57$ & $16.1 \pm 5.6$ \\
\hline Base of the mixed layer (oxic zone; $104 \mu \mathrm{M}$ ) & Control & $-0.29 \pm 0.06$ & $\mathrm{~nm}$ & $\mathrm{~nm}$ \\
\hline (15 m, size-fractionated) & $\mathrm{CX}$ & $-17.71 \pm 0.67$ & $\mathrm{~nm}$ & $\mathrm{~nm}$ \\
\hline Upper border of the OMZ (suboxic zone; $5 \mu \mathrm{M}$ ) & Control & $-0.002 \pm 0.01$ & $\mathrm{~nm}$ & $\mathrm{~nm}$ \\
\hline (50 m, size-fractionated) & $\mathrm{CX}$ & $-14.13 \pm 0.63$ & $\mathrm{~nm}$ & $\mathrm{~nm}$ \\
\hline
\end{tabular}

positive or almost zero values in the controls $(t$-test, $\mathrm{p}<$ 0.001) in both kinds of experiments indicated net $\mathrm{NH}_{4}^{+}$ prokaryote consumption rates, ranging between -3.86 and $-17.71 \mu \mathrm{M} \mathrm{d}^{-1}\left(\mathrm{CX}_{i}\right.$ Table 2$)$. At these depths, therefore, eukaryotes, which are only active in the control, support the high prokaryote $\mathrm{NH}_{4}{ }^{+}$consumption through net $\mathrm{NH}_{4}{ }^{+}$regeneration rates of between 4.6 and $17.7 \mu \mathrm{M} \mathrm{d}^{-1}$ (Fig. 3). Eukaryote $\mathrm{NH}_{4}{ }^{+}$consumption was not evident in any of the depths sampled since $\mathrm{NH}_{4}{ }^{+}$accumulation was not higher in the CX treatment than in the control.

\section{$\mathrm{NH}_{4}{ }^{+}$and $\mathrm{NO}_{2}{ }^{-}$oxidation in the oxycline and suboxic zones}

Natural $\mathrm{NH}_{4}{ }^{+}$oxidation was only observed in the oxycline zone, based on the slightly higher $\mathrm{NH}_{4}{ }^{+}$and $\mathrm{NO}_{2}{ }^{-}$appearance rates in the ATU treatment and the control, in comparison with the control and the ATU treatment, respectively (Table 2). The differences among these treatments were not significant $(t$-test, $\mathrm{p}>$ 0.05) and, therefore, no $\mathrm{NH}_{4}{ }^{+}$oxidation rates were computed. In the suboxic zone, an unexpected higher $\mathrm{NH}_{4}{ }^{+}$accumulation in the control with respect to ATU treatment was found, coinciding with $\mathrm{NO}_{2}^{-}$and $\mathrm{NO}_{3}{ }^{-}$ disappearance rates (Table 2), and prevented the evaluation of $\mathrm{NH}_{4}{ }^{+}$oxidation.

Potential $\mathrm{NH}_{4}{ }^{+}$oxidation rates were obtained in the oxycline and suboxic zones. In the oxycline zone, a potential $\mathrm{NH}_{4}{ }^{+}$oxidation rate of $0.56 \mu \mathrm{M} \mathrm{d}^{-1}$ (Fig. 3) was estimated only through $\mathrm{NO}_{2}^{-}$rates of change, which showed a higher $\mathrm{NO}_{2}^{-}$accumulation in $\mathrm{CX}$ treatment with respect to the ATU + CX treatment $(t-$
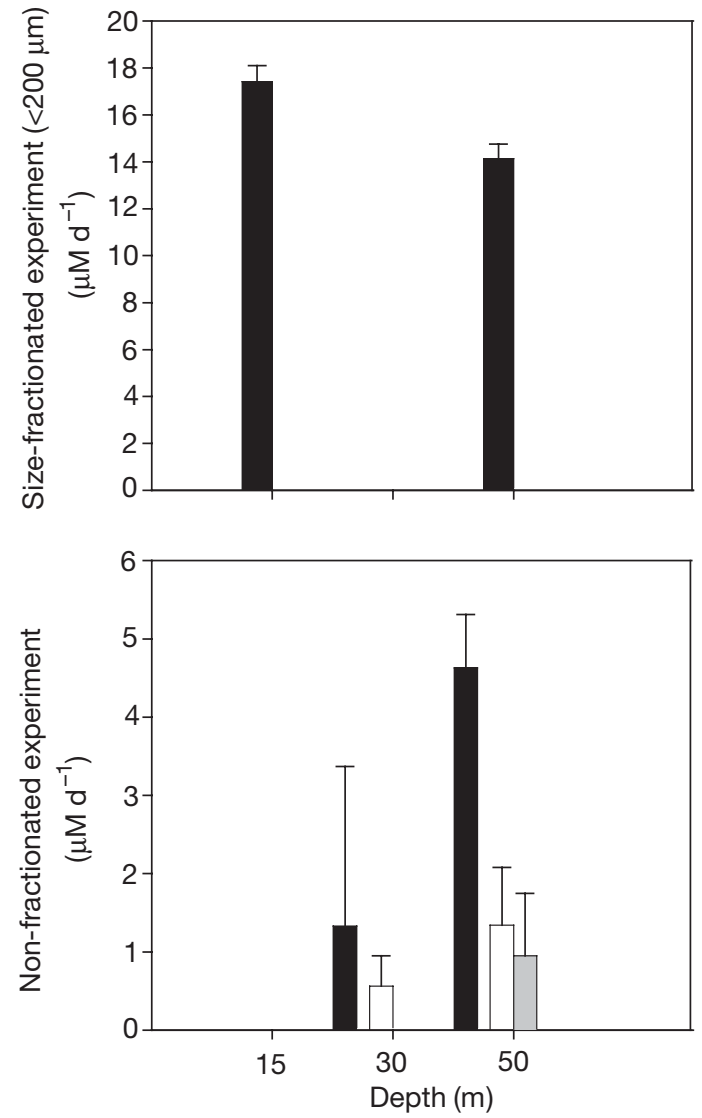

Fig. 3. $\mathrm{Net} \mathrm{NH}_{4}{ }^{+}$regeneration rates (black bars) in non-fractionated and size-fractionated $(<200 \mu \mathrm{m})$ experiments evaluated at $15 \mathrm{~m}$, the base of the mixed layer (oxic zone; $104 \mu \mathrm{M}$ ), at $30 \mathrm{~m}$, the oxycline (low-DO zone; $69 \mu \mathrm{M}$ ), and at the upper boundary of the OMZ (suboxic zone; $5 \mu \mathrm{M}$ ). Potential $\mathrm{NH}_{4}{ }^{+}$ oxidation rates, obtained from $\mathrm{NO}_{2}^{-}$(open bars) and $\mathrm{NH}_{4}{ }^{+}$ cycling rates (grey bar) in the oxycline and suboxic zones 
test, $\mathrm{p}=0.03)$. In the suboxic zone, 2 potential $\mathrm{NH}_{4}^{+}$ oxidation rates were obtained: (1) a rate of $1.34 \mu \mathrm{M} \mathrm{d}^{-1}$ (Fig. 3), derived from the significant difference ( $t$-test, $\mathrm{p}=0.02$ ) in the $\mathrm{NO}_{2}{ }^{-}$rate of change in the $\mathrm{CX}$ versus ATU + CX treatments (Table 2), and (2) a rate of $0.95 \mu \mathrm{M} \mathrm{d}^{-1}$ (Fig. 3), obtained from the difference in the $\mathrm{NH}_{4}{ }^{+}$rates of change between the CX and ATU + CX treatments ( $t$-test, $\mathrm{p}=0.04$ ), and based on the higher $\mathrm{NH}_{4}{ }^{+}$accumulation in the latter treatment (Table 2).

$\mathrm{NO}_{2}^{-}$oxidation was directly observed through the $\mathrm{NO}_{2}{ }^{-}$disappearance rate in the ATU and ATU + CX amended treatments only in the suboxic zone $(-0.26$ to $-0.67 \mu \mathrm{M} \mathrm{d}^{-1}$; Table 2). The presence of $\mathrm{NO}_{2}^{-}$oxidation was, however, indirectly detected through $\mathrm{NO}_{3}{ }^{-}$ appearance rate in both the oxycline and the suboxic zones (Table 2). Moreover, in the oxycline zone, $\mathrm{NO}_{3}{ }^{-}$ rates of change were higher and positive in the control and the CX treatments with respect to the ATU and $\mathrm{ATU}+\mathrm{CX}$ treatments ( $t$-test, $\mathrm{p}=0.03$ and 0.006, respectively).

\section{DISCUSSION}

\section{Eukaryote and prokaryote contribution to net $\mathrm{NH}_{4}{ }^{+}$regeneration and consumption}

$\mathrm{NH}_{4}{ }^{+}$regeneration is usually evaluated by combining size fractionation with isotope $\mathrm{N}$ experiments, in order to assess the main planktonic size fraction contributing to $\mathrm{NH}_{4}^{+}$production carried out by heterotrophic metabolism (excretion or remineralisation, Table 1). These results have indicated that $\mathrm{NH}_{4}{ }^{+}$ regeneration mainly occurs via small heterotrophs, the $<10 \mu \mathrm{m}$ (nanoplankton) and the $<1 \mu \mathrm{m}$ (mostly prokaryotes or bacterioplankton) fractions (e.g. Glibert 1982). The use of inhibitors in this study allowed us to separate prokaryote from eukaryote influence on net $\mathrm{NH}_{4}{ }^{+}$regeneration in the water column; it was found that their relative contribution was variable within the top $50 \mathrm{~m}$. In the oxycline zone, prokaryotes were the main $\mathrm{NH}_{4}{ }^{+}$producers, whereas in the oxic $(<200 \mu \mathrm{m}$ size fraction incubation) and suboxic $(<200 \mu \mathrm{m}$ and non-fractionated incubations) zones, eukaryotes were the main $\mathrm{NH}_{4}^{+}$contributors. Moreover, in the 2 latter zones, there were higher abundances of HNF compared with those in the oxycline zone (Fig. 2). The net $\mathrm{NH}_{4}{ }^{+}$regeneration rates evaluated here are in the upper range and higher than the rates obtained from isotope $\mathrm{N}$ experiments in other coastal and upwelling areas (e.g. $\leq 6.5 \mu \mathrm{M} \mathrm{d}^{-1}$; Glibert 1982, Wheeler \& Kirchman 1986, Probyn 1987, Metzler et al. 2000, Varela et al. 2003), and in mesotrophic lake environments (e.g. 0.26 to $6.2 \mu \mathrm{M} \mathrm{d}^{-1}$; Haga et al. 1995).
The use of inhibitors in our study also allowed an estimation of $\mathrm{NH}_{4}{ }^{+}$consumption, which can be mainly attributed to 2 kinds of metabolisms, photoautotrophy (eukaryote and prokaryote) or heterotrophy (prokaryotes). $\mathrm{NH}_{4}{ }^{+}$uptake under dark conditions could be diminished by $\sim 70 \%$ compared with light conditions (Gardner et al. 2004), indicating the predominance of photoautotrophic metabolism. In other environments, however, heterotrophic bacteria could contribute largely to total $\mathrm{NH}_{4}{ }^{+}$uptake, even under light conditions (e.g. 79\%, Tungaraza et al. 2003). In this study, $\mathrm{NH}_{4}{ }^{+}$consumption by eukaryotes was not evident because $\mathrm{NH}_{4}{ }^{+}$was always produced in the control with respect to the $\mathrm{CX}$ treatment. In contrast, a net $\mathrm{NH}_{4}{ }^{+}$prokaryote consumption $(-3.86$ to $-17.71 \mu \mathrm{M}$ $\mathrm{d}^{-1}$ ) was observed in the oxic and suboxic zones, at rates comparable with those reported for heterotrophic bacterial potential $\mathrm{NH}_{4}{ }^{+}$uptake rates (e.g. 4.6 to $14.6 \mu \mathrm{M} \mathrm{d}^{-1}$; Wheeler \& Kirchman 1986, Kirchman \& Wheeler 1998). In addition, coincident high bacteria and cyanobacteria abundances were found at these depths (Fig. 2).

Except for AOB activity, the net $\mathrm{NH}_{4}{ }^{+}$prokaryote consumption reported herein could not be attributed to a specific type of metabolism, namely, photoautotrophic or heterotrophic. Dark incubations do not necessarily avoid photoautotrophic $\mathrm{N}$ uptake. In fact, darkness does not appear to significantly affect glutamine synthetase (an enzyme involved in $\mathrm{NH}_{4}{ }^{+}$assimilation) activity in Prochlorococcus sp., cyanobacteria that were detected at $50 \mathrm{~m}$ depth in our study area by flow cytometry (O. Ulloa unpubl. data); this is probably attributed to a low light adaptation mechanism (Alaoui et al. 2001).

\section{$\mathrm{NH}_{4}{ }^{+}$oxidation and $\mathrm{N}$ electron acceptor regeneration in the upper boundary of the $\mathrm{OMZ}$}

$\mathrm{NH}_{4}{ }^{+}$oxidation was qualitatively observed under natural substrate conditions but only quantitatively estimated in experiments with $\mathrm{NH}_{4}{ }^{+}$addition, indicating that $\mathrm{AOB}$ activity was limited by substrate. The potential $\mathrm{NH}_{4}{ }^{+}$oxidation rates measured in this study are in the range of those previously reported for the upper boundary of the OMZ off northern Chile and Peru ( 0 to $0.96 \mu \mathrm{M} \mathrm{d}^{-1}$; Ward et al. 1989, Lipschultz et al. 1990, L.F. unpubl. data), and for other eutrophic areas (e.g. 0.23 to $2.15 \mathrm{mM} \mathrm{d}^{-1}$; Feliatra \& Bianchi 1993). These rates were higher in the suboxic zone compared with the oxycline zone $(>50 \%)$, a difference that could be attributed to a quick metabolic adjustment of AOB to more favourable DO conditions during the incubation (e.g. Bodelier et al. 1996). In the oxycline and suboxic zones, potential $\mathrm{NH}_{4}{ }^{+}$oxidation 
rates represented 42 and 20 to $29 \%$ of net $\mathrm{NH}_{4}^{+}$ regeneration, respectively; in the latter, the remaining 71 to $80 \%$ could have been taken up by other prokaryotes $\left(\mathrm{NH}_{4}{ }^{+}\right.$disappearance in the CX-amended treatment). In the oxycline zone, however, the remaining $\mathrm{NH}_{4}{ }^{+}$did not appear to have been used but rather accumulated.

The activities of $\mathrm{AOB}$ and $\mathrm{NO}_{2}^{-}$-oxidizing bacteria (NOB) led to the regeneration of the electron acceptors $\mathrm{NO}_{2}^{-}$and $\mathrm{NO}_{3}^{-}$, which in turn are used for $\mathrm{NO}_{3}{ }^{-}$ reduction and denitrification, the main process responsible for $\mathrm{N}$ loss in OMZs (Codispoti et al. 2001). Exploring AOB and NOB coupling could be indicative of the state of nitrification and, thus, of the main electron acceptor regenerated and potentially usable. In the oxycline zone, an AOB and NOB activity coupling was detected through the higher $\mathrm{NO}_{3}{ }^{-}$ appearance rate in the control and the CX treatment, where both bacterial groups are active, in comparison with the ATU treatment where AOB are inhibited (Table 2). In the suboxic zone, by comparing AOB (0.95 to $1.34 \mu \mathrm{M} \mathrm{d}^{-1}$ ) with NOB (0.26 to $0.67 \mu \mathrm{M} \mathrm{d}^{-1}$ ) activities, 19 to $70 \%$ of coupling was found. NOB activity is expected to be underestimated when using $\mathrm{NO}_{2}{ }^{-}$disappearance rate in the ATU treatment, according to the high $\mathrm{NO}_{3}{ }^{-}$production rate obtained under this condition (Table 2). In fact, in the oxycline and the suboxic zones, $\mathrm{NO}_{2}^{-}$produced by $\mathrm{AOB}$ represented $\leq 10 \%$ of total $\mathrm{NO}_{3}{ }^{-}$production, which means that $\mathrm{NO}_{3}{ }^{-}$was built up from a different $\mathrm{NO}_{2}{ }^{-}$source than $\mathrm{NH}_{4}{ }^{+}$oxidation in our incubations. In the oxycline zone, the higher $\mathrm{NO}_{3}^{-}$production rates in the treatments where eukaryotes should be more active (control and ATU), suggest that eukaryotes influence $\mathrm{NO}_{3}{ }^{-}$cycling, probably through the potential release of $\mathrm{NO}_{2}^{-}$, which may be immediately used by NOB. This influence could be based on photoautotrophic $\mathrm{NO}_{2}{ }^{-}$release (e.g. Falkowski \& Raven 1997); under unfavourable light conditions (as at the bottom of the euphotic zone), phytoplankton active release of $\mathrm{NO}_{2}^{-}$ is a mechanism which is used to explain the formation of the primary $\mathrm{NO}_{2}^{-}$maximum in the oceans (e.g. Kiefer et al. 1976).

\section{Potential incubation biases and their effects on $\mathrm{NH}_{4}{ }^{+}$cycling rates}

CX did not significantly influence the abundance of planktonic organisms after $4 \mathrm{~h}$ incubation (data not shown); however, $\mathrm{NH}_{4}{ }^{+}$enrichment by $\mathrm{CX}$ could have stimulated prokaryote $\mathrm{NH}_{4}{ }^{+}$consumption, resulting in an overestimation of net $\mathrm{NH}_{4}{ }^{+}$regeneration as compared with isotope $\mathrm{N}$ experiment values. The rates calculated using $\mathrm{CX}$ versus control data from
Wheeler \& Kirchman (1986), however, were in the upper range and higher than the ones obtained from isotope $\mathrm{N}$ experiments in the same study (2.7 to $40.8 \mu \mathrm{M} \mathrm{d}^{-1}$ ). Other potential incubation biases could also result in an overestimation of the net $\mathrm{NH}_{4}^{+}$ regeneration rates, mainly in the oxic and suboxic zones, through a stimulation of $\mathrm{NH}_{4}{ }^{+}$uptake by the higher temperature used in the size-fractionated experiments $\left(\sim 17^{\circ} \mathrm{C}\right)$.

Potential biases associated with DO increase during sampling and distribution of water into experimental bottles could only be an important issue in the suboxic zone experiments. In this zone, a differential oxygenation was expected between the control and the rest of the treatments. In the control, a higher $\mathrm{NH}_{4}{ }^{+}$accumulation (with respect to the ATU treatment) and $\mathrm{NO}_{3}{ }^{-}$ and $\mathrm{NO}_{2}^{-}$disappearance rates were observed, probably associated with a $\mathrm{NH}_{4}{ }^{+}$oxidation decrease and the presence of reduction processes, respectively, both being the most sensitive processes to DO change. The expected level of oxygenation in CX, ATU, ATU + CX treatments could, therefore, be associated with DO thresholds in the $\mathrm{NO}_{3}{ }^{-}$reduction enzymes $\left(\geq 88 \mu \mathrm{M}_{\text {; }}\right.$ e.g. Körner \& Zumft 1989). Other processes, such as eukaryote $\mathrm{NH}_{4}{ }^{+}$regeneration, are not expected to be affected by DO increase since aeration does not seem to influence HNF grazing in hypoxic zones (Park \& Cho 2002).

The present results on $\mathrm{NH}_{4}{ }^{+}$cycling through different types of contributors (prokaryotes and eukaryotes) provide, on the one hand, evidence of the importance of eukaryotes in supporting prokaryotic $\mathrm{N}$ needs, including uptake and oxidation processes. On the other hand, they allow the identification of a prokaryote-dominated layer in the water column characterised by sharp physical-chemical gradients that are associated with the OMZ. The presence of these features and the cycling processes should be further examined over wider spatial and temporal scales to understand the biogeochemical $\mathrm{N}$ cycling in this intense OMZ region.

Acknowledgements. We acknowledge C. Rivera, G. Alarcón and V. Villagrán for their technical support in the lab and in the field work; and the University of Antofagasta for providing transportation facilities during this cruise. We thank 3 anonymous reviewers and $\mathrm{O}$. Ulloa for comments and suggestions that improved the manuscript. This research was financed by the Comisión Nacional de Investigaciones Científicas y Tecnológicas (CONICYT) with the FONDECYT Grant No. 1030741 and the FONDAP-COPAS Center for Oceanographic Research in the eastern South Pacific (Project No. 150100007). V.M. was supported by Fundación Andes and MECESUP UCO002 PhD grants. L.F. and C.E.M. were also supported by the Advanced Groups Initiative of the Directorate of Research at the Universidad de Concepción. 


\section{LITERATURE CITED}

Alaoui SE, Diez J, Humanes L, Toribio F, Partensky F, GarcíaFernández JM (2001) In vivo regulation of glutamina synthetase activity in the marine chlorophyll b-containing cyanobacterium Prochlorococcus sp. Strain PCC 9511 (oxyphotobacteria). Appl Environ Microbiol 67:2202-2207

Bianchi M, Feliatra F, Tréguer P, Vincendeau MA, Morvan J (1997) Nitrification rates, ammonium and nitrate distribution in upper layers of the water column and in sediments of the Indian sector of the Southern Ocean. Deep-Sea Res 44:1017-1032

Blanco JL, Thomas AC, Carr ME, Strub PT (2001) Seasonal climatology of hydrographic conditions in the upwelling region off northern Chile. J Geophys Res 106:11-467

Bodelier PLE, Libochant JA, Blom CWPM, Laanbroek HJ (1996) Dynamics of nitrification and denitrification in rootoxygenated sediments and adaptation of ammoniaoxidizing bacteria to low-oxygen or anoxic habitats. Appl Environ Microbiol 62:4100-4107

Brandhorst W (1971) Condiciones oceanográficas estivales frente a la costa de Chile. Rev Biol Mar 14:45-84

Campbell L, Carpenter EJ (1986) Estimating the grazing pressure of heterotrophic nanoplankton on Synechococcus spp. using the sea water dilution and selective inhibitor techniques. Mar Ecol Prog Ser 33:121-129

Codispoti LA, Brades JA, Christensen JP, Devol AH, Naqvi SWA, Paerl HW, Yoshinari T (2001) The oceanic fixed nitrogen and nitrous oxide budgets: moving targets as we enter the anthropocene? Sci Mar 65:85-105

Daneri G, Dellarrosa V, Quiñones R, Jacob B, Montero P, Ulloa O (2000) Primary production and community respiration in the Humboldt Current System off Chile and associated oceanic areas. Mar Ecol Prog Ser 197:41-49

Falkowski PG, Raven JA (1997) Aquatic photoshyntesis. Blackwell Science, Oxford

Feliatra F, Bianchi M (1993) Rates of nitrification and carbon uptake in the Rhône River Plume (northwestern Mediterranean Sea). Microb Ecol 26:21-28

Fischer H, Pusch M (1999) Use of the $\left[{ }^{14} \mathrm{C}\right]$ leucine incorporation technique to measure bacterial production in river sediments and the epiphyton. Appl Environ Microbiol 65: 4411-4418

Gardner WS, Lavrentyev PJ, Cavaletto JF, McCarthy MJ, Eadie BJ, Johengen TH, Cotner JB (2004) Distribution and dynamics of nitrogen and microbial plankton in southern Lake Michigan during spring transition 1999-2000. J Geophys Res 109:1-16

Glibert PM (1982) Regional studies of daily seasonal and size fractionation variability in ammonium remineralization. Mar Biol 70:209-222

Goericke R, Olson RJ, Shalapyonok A (2000) A novel niche for Prochlorococcus sp. in low-light suboxic environments in the Arabian Sea and the Eastern Tropical North Pacific. Deep-Sea Res 41:1183-1205

Haga $H$, Nagata T, Sakamoto M (1995) Size-fractionated $\mathrm{NH}_{4}{ }^{+}$regeneration in the pelagic environments of two mesotrophic lakes. Limnol Oceanogr 40:1091-1099

Holmes RM, Aminot A, Kérouel R, Hooker BA, Peterson BJ (1999) A simple and precise method for measuring ammonium in marine and freshwater ecosystems. Can J Fish Aquat Sci 56:1801-1808

Iriarte JL, González HE (2004) Phytoplankton size structure during and after the 1997/1998 El Niño in a coastal upwelling area of the northern Humboldt Current System. Mar Ecol Prog Ser 269:83-90
Kamykowski D, Zentara S-J (1990) Hypoxia in the world ocean as recorded in the historical data set. Deep-Sea Res 37:1861-1874

Kiefer DA, Olson RJ, Holm-Hansen O (1976) Another look at the nitrite and chlorophyll maxima in the central North Pacific. Deep-Sea Res 23:1199-1208

Kirchman DL, Wheeler PA (1998) Uptake of ammonium and nitrate by heterotrophic bacteria and phytoplankton in the sub-Arctic Pacific. Deep-Sea Res 45:347-365

Körner H, Zumft WG (1989) Expression of denitrification enzymes in response to the dissolved oxygen level and respiratory substrate in continuous culture of Pseudomonas stutzeri. Appl Environ Microbiol 55:1670-1676

Lam P, Cowen JP, Jones RD (2004) Autotrophic ammonia oxidation in a deep-sea hydrothermal plume. FEMS Microbiol Ecol 47:191-206

Lipschultz F, Wofsy SC, Ward BB, Codispoti LA, Friedrich G, Elkins JW (1990) Bacterial transformations of inorganic nitrogen in the oxygen deficient waters of the Eastern Tropical South Pacific Ocean. Deep-Sea Res 37:1513-1541

Maguer JF, L'Helguen S, Madec C, Le Corre P (1999) Seasonal patterns of ammonium regeneration from sizefractionated microheterotrophs. Cont Shelf Res 19: $1755-1770$

Metzler P, Glibert PM, Gaeta SA, Ludlam JM (2000) Contrasting effects of substrate and grazer manipulations on picoplankton in oceanic and coastal waters off Brazil. J Plankton Res 22:77-90

Morales CE, Hormazábal SE, Blanco JL (1999) Interannual variability in the mesoscale distribution of the depth of the upper boundary of the oxygen minimum layer off northern Chile $\left(18-24^{\circ} \mathrm{S}\right)$ : implications for the pelagic system and biogeochemical cycling. J Mar Res 57:909-932

Park JS, Cho BC (2002) Active heterotrophic nanoflagellates in the hypoxic water-column of the eutrophic Masan Bay, Korea. Mar Ecol Prog Ser 230:35-45

Parsons T, Maita Y, Lalli CM (1984) A manual of chemical and biological methods for seawater analysis. Pergamon Press, Oxford

Porter KG, Feig YS (1980) The use of DAPI for identifying and counting aquatic microflora. Limnol Oceanogr 25:943948

Probyn TA (1987) Ammonium regeneration by microplankton in an upwelling environment. Mar Ecol Prog Ser 37:53-64

Tungaraza C, Brion N, Rousseau V, Baeyens W, Goeyens L (2003) Influence of bacterial activities on nitrogen uptake rates determined by the application of antibiotics. Oceanol 45:473-489

Varela MM, Barquero S, Bode A, Fernández E, González N, Teira E, Varela M (2003) Microplanktonic regeneration of ammonium and dissolved organic nitrogen in the upwelling area of the NW of Spain: relationships with dissolved organic carbon production and phytoplankton size-structure. J Plankton Res 25:719-736

Vargas CA, González H (2004) Plankton community structure and carbon cycling in a coastal upwelling system. II. Microheterotrophic pathway. Aquat Microb Ecol 34:165-180

Ward BB, Glover HE, Lipschultz F (1989) Chemoautotrophic activity and nitrification in the oxygen minimum zone off Peru. Deep-Sea Res 36:1031-1051

Wheeler PA, Kirchman DL (1986) Utilization of inorganic and organic nitrogen by bacteria in marine systems. Limnol Oceanogr 31:998-1009

Williams PJ, Jenkinson NW (1982) A transportable microprocessor controlled precise Winkler titration suitable for field station and shipboard use. Limnol Oceanogr 27: $576-584$

Submitted: March 2, 2004; Accepted: October 21, 2004

Proofs received from author(s): February 28, 2005 